\title{
CORRECTION
}

\section{Correction to: Leadership Training and Undergraduate Medical Education: a Scoping Review}

Eric James ${ }^{1} \cdot$ Mallory Evans ${ }^{1} \cdot$ Misa Mi $^{2}$

Published online: 6 July 2021

(C) International Association of Medical Science Educators 2021

Correction to: Medical Science Educator https://doi.org/10.1007/s40670-021-01308-9

The original article has been updated to correct the reference list and the citations.
Publisher's Note Springer Nature remains neutral with regard to jurisdictional claims in published maps and institutional affiliations.

The original article can be found online at https://doi.org/10.1007/ s40670-021-01308-9.

Eric James

ejjames@oakland.edu

1 Oakland University, William Beaumont School of Medicine,

Rochester, MI, USA

2 Department of Foundational Medical Studies, Oakland

University, William Beaumont School of Medicine,

Rochester, MI, USA 